\title{
H. G. WELLS, GEOLOGY, AND THE RUINS OF TIME
}

\author{
By David Shackleton
}

H. G. Wells's ThE TIME MACHINE (1895) has hitherto been read in two principal scientific contexts: those of evolutionary biology and thermodynamic physics. Numerous critics have situated the romance in the context of evolutionary biology and contemporary discourses of degeneration (McLean 11-40; Greenslade 32-41). Others have discussed it in the context of thermodynamic physics. For instance, Bruce Clarke has read The Time Machine as "a virtual allegory of classical thermodynamics," and shows that its combination of physical and social entropy reflects a wider transfer within the period of concepts and metaphors from physical science to social discourses of degeneration (121-26). Neatly linking these scientific contexts with issues of form, Michael Sayeau has argued that the social and physical entropy that are themes of the romance are reflected in its narrative structure, which manifests a type of narrative entropy, and thereby raises the spectre of the end of fiction (109-46).

Collectively, these critics have demonstrated that the future world which the Time Traveller visits is one beset by evolutionary retrogression, in which humanity has degenerated into two species before possibly suffering extinction, and one approaching heat-death, as a consequence of the second law of thermodynamics and the "dissipation of mechanical energy" (Thomson 511). That is, they have shown how Wells, by drawing on discourses of evolutionary biology and thermodynamic physics, fashioned his own narrative of a degenerating humanity and a slowly dying earth.

However, while critics have paid ample attention to evolutionary biology and thermodynamic physics, they have almost entirely overlooked geological discourse. Certainly, critics such as Frank McConnell and Simon James have mentioned both geology and geological time in their discussions of The Time Machine. For example, McConnell long ago suggested that "[w]hat Wells manages to do in The Time Machine is to articulate, for the first time and decisively for his age, a vision of the abyss of geological time" (82). More recently, James has astutely noted that "The Time Machine's engagement with Victorian science draws not only on biology's reimagining of human physiology, but also on geology's expansion of the Victorian sense of time" (56-57). Yet beyond such passing references, there has not been a sustained discussion of The Time Machine in the context of geology. This comparative neglect is characteristic of a wider tendency in both the history of science and in literary criticism. In the former, as Martin Rudwick points out, geology's historicization of the earth "has generally been treated as a mere prelude to the better-known story of the 'Darwinian revolution'” (Bursting 7). Similarly, as Adelene Buckland has noted, geology 
has until recently received something of a "raw deal" in literary studies, tending to be cast as a mere handmaiden of evolutionary biology (24).

The oversight is surprising given that, by the time he wrote The Time Machine, Wells was well-versed in geology. ${ }^{1}$ He studied geology at the Normal School of Science, where he sat examinations in the subject in 1886 and 1887 . While, as he records in his autobiography, he failed the latter exam, he later took "first place in second class honours in geology" in his B.Sc. degree, which was awarded by London University in 1890 (233). He subsequently taught geology classes at the University Tutorial College, London, and co-wrote a text-book called Honours Physiography (1893). This text-book was designed to prepare students at the Royal College of Science for the "Honours Examination" in Physiography, which covered geology, astronomy, and meteorology. ${ }^{2}$ As its preface claims, "Honours Physiography involves a sound knowledge of geological structures in general, and the forces moulding them"; the book includes a section on "The Age of the Earth," and a final chapter on the "Distribution of Life in Space and Time" (i). In 1894, Wells reviewed T. G. Bonney's The Story of our Planet (1893), which advertises itself as a non-technical and accessible introduction to geology in the tradition of James Hutton and Charles Lyell's uniformitarianism. Wells praised Bonney's book as an "able and popular exposition of modern geology," and predicted that it would "be very widely read" ("Reminiscences" 4). More generally, by late-Victorian times, geology had become an established scientific discipline of considerable prestige and authority, and featured prominently in the work of major scientific popularisers such as T. H. Huxley (O'Connor 436-39).

Regardless of the reasons for its comparative neglect, situating The Time Machine in the context of geology is rewarding. It provides insight into the conceit of time travel, the ruined architecture of the future age, and the work's fragmentary aesthetic. Martin Willis has suggested that it is through their employment of shared forms of imagination that science and literature are most closely linked in the Victorian and Edwardian periods (8-9). In the case of geology, imagination played an important role in the construction and acceptance of the concept of geological time, both in foundational works such as Lyell's Principles of Geology (1830-33), and in the various media through which geology was marketed as a popular spectacle. Here, I will argue that The Time Machine redeploys such forms of the geological imagination in its fictional tale of the Traveller's adventures in deep time. However, while it draws on such ways of imagining deep time, it simultaneously contains an implicit critique of the commodification of deep time, by which the history of the earth was laid bare for spectacular consumption.

\section{Geological Time Travel}

In THE TIME MACHINE (1895), the Time Traveller makes two principal journeys into the future, before returning home: firstly to the year 802,701 A.D., and secondly to "more than thirty million years hence" $(28,84))^{3}$ The conceit of time travel which is central to this romance finds a precedent in that which Ralph O'Connor calls "geological time travel," or the idea of being carried back into antiquity, which became a commonplace in geological literature (372-74). ${ }^{4}$ In particular, the early stages of the Traveller's journey resemble the geological time travel described in Lyell's Principles of Geology. ${ }^{5}$

Lyell recognized the importance of imagination as a means of gaining widespread acceptance for the idea of a vast geological time. Indeed, Rudwick argues that although many 
of Lyell's scientific colleagues already accepted a vast age for the earth as an intellectual working assumption, Lyell "seems to have recognized that it was their scientific imagination that needed transforming" ("Strategy" 11). Thus, in the Principles, he advocated reckoning the geological "myriads of ages" not "by arithmetical computation," but rather by "a train of physical events": "signs which convey to our minds more definite ideas than figures can do, of the immensity of time." The geologist is portrayed as imagining physical changes through time in a visual and dynamic manner: "to trace the same system through various transformations - to behold it at successive eras adorned with different hills and valleys, lakes and seas, and peopled with new inhabitants, was the delightful meed of geological research" (Lyell 25). Wells's romance provides a very concrete version of such an imaginative exercise. The Traveller builds a time machine, and literally - as opposed to imaginatively - watches the ages passing as he voyages through deep time.

Of course, there are differences between Wells's and Lyell's geological journeys. Lyell's is an imaginative journey, and the geologist is able to "behold" the changes wrought on the landscape only with the mind's eye, whereas the Traveller is literally able to watch these changes. Moreover, geological time travel typically involved voyaging back into antiquity, whereas Wells's Time Traveller sets out into the future. Nevertheless, the similarities are pronounced. The Traveller records how, travelling on his time machine, he "saw trees growing and changing like puffs of vapour,... they grew, spread, shivered, and passed away. I saw huge buildings rise up... and pass like dreams. The whole surface of the earth seemed changed - melting and flowing under my eyes" (19). His watching the "whole surface of the earth" changing before his eyes, and buildings rise and "pass like dreams," parallels Lyell's description of the geologist beholding the earth at "successive eras adorned with different hills and valleys," and "peopled with new inhabitants." In The Time Machine, the "melting and flowing" of the surface of the earth also echoes Alfred Tennyson's In Memoriam (1850), in which the hills "flow" and "melt like mist":

The hills are shadows, and they flow

From form to form, and nothing stands;

They melt like mist, the solid lands,

Like clouds they shape themselves and go. $(123,5-8)$

This stanza both displays the influence of Lyell's conception of geological time on In Memoriam, and was itself later quoted in geological works. ${ }^{6}$ For example, in The Story of Our Planet (1893), which Wells reviewed in 1894, Bonney used the first two lines of this stanza to conclude his chapter on the geological construction of the British Isles, where they complement his point that the earth's surface is "never at rest," but "rises and falls, as if it were the breast of some huge monster, slowly breathing as it sleeps" (448, 221). ${ }^{7}$ Later in The Time Machine, the Traveller records during his return voyage that " $[\mathrm{t}] \mathrm{he}$ fluctuating contours of the land ebbed and flowed" (86). In the National Observer version, he witnesses the hills being eroded: "I noticed the hills grow visibly lower through the years with the wear of the gust and rain" (Early Writings 64). The conceit of the time machine allows the Traveller to watch the infinitesimally slow changes of geology and astronomy that normally, as he points out, remain "imperceptible in a hundred human lifetimes" $(60$ 61). This way of making visible slow change through vast periods of time is a fictional equivalent of Lyell's geological imagination, and his advocacy of reckoning the "myriad 
of ages" not through arithmetical computation, but visually, through trains of physical events.

Wells's conceit of time travel also finds a precedent in the various popular visual and theatrical displays that, informed by recent geological science, portrayed themselves as time travel into distant geological epochs. ${ }^{8}$ As well as the prose passages in geological works that allowed readers to form visual images of the earth's history in their "mind's eye," O'Connor has shown the importance of such forms of virtual tourism to the popular imagination of deep time (263-324). In Wells's romance, the Traveller's experience as he travels through time is similar to that offered by theatrical displays such as dioramas, in which the audience viewed a series of illuminated scenes that gave the impression of time passing, often tracing the progress from day to night or the dispersal of mist. Indeed, the Traveller watches his laboratory grow "dim" as night falls, and remarks that the landscape appeared "misty" (19). Again, his description of the surface of the earth "melting" and "flowing" parallels the magic lantern displays and phantasmagoria that geological lecturers used as visual aids from the 1830 s onwards. These aids presented the history of the earth as a series of "dissolving views," in which one scene melted into another to give the impression of a changing landscape (O'Connor 271-73). The dreamlike and insubstantial nature of the scenes the Traveller witnesses - seemingly "built of glimmer and mist" - are like the images offered by such popular forms of geological time travel.

In line with the uniformitarian geology of Lyell and others, geological change in The Time Machine consists of very small alterations over vast periods, as opposed to dramatic changes wrought by violent geological catastrophes. Once the Traveller has arrived in the world of the Eloi and Morlocks, he notices subtle changes to the topography. After over 800,000 years, "the Thames had shifted, perhaps, a mile from its present position," and when he reaches the Palace of Green Porcelain, he "was surprised to see a large estuary, or even a creek, where [he] judged Wandsworth and Battersea must once have been" $(28,64)$. In the world approaching heat-death, the Traveller, whose machine has not moved through space, finds himself on the edge of a sloping beach by a sea (82). A process of geological change has taken place incrementally over the intervening time-span, much like that highlighted in Tennyson's In Memoriam:

\footnotetext{
There rolls the deep where grew the tree.

$\mathrm{O}$ earth, what changes hast thou seen!

There where the long street roars, hath been

The stillness of the central sea. $(123,1-4)$
}

Bonney quotes this stanza in his Story of our Planet, and comments that "[t]he poet uttered no dreamer's words, but simple scientific truth" (222). In Tennyson's poem, the poet thinks that "where the long street roars, hath been/ The stillness of the central sea," whereas in The Time Machine, what had been central London comes in the distant geological future to be covered by a freezing sea. ${ }^{9}$

The geological aspects of the Traveller's time travel are developed further in an abandoned draft chapter of The Time Machine, called "The Return of the Time Traveller."10 In this chapter, the Traveller returns from the "desolate beach of the dying Earth," but overshoots his mark, and ends up in the remote geological past. He becomes "lost in time," and tries to recall the geological works that he has read to locate himself. However, to his 
disadvantage, his geological knowledge is comically bad. He reasons that: "[s]o far as my knowledge of geology went this river might be the great flood that deposited what is now the London Clay." Below, in what is perhaps a joke at his own expense, having failed the geological exam at the Normal School of Science in 1887, Wells adds a footnote that criticises the Traveller's supposition:

The Time Traveller's knowledge of geology was scarcely on a level with his mechanical acquirements. A distinguished geologist assures me that this supposition was quite inaccurate.... [T] he hippopotamus [which the Traveller encountered]... would indicate the much more recent epoch of the Pliocene period. (Definitive 185)

Initially, the Traveller had worried that he would "stop when the country was submerged, $\&$ sink plump into the water of some of those vanished oceans whose sediments form the dry land of today." Fortunately, however, he comes to rest on the bank of a prehistoric river delta, and eventually manages to return home safely (Definitive 184-86).

The Traveller's second voyage through time resembles more sublime forms of geological time travel. It was not just the ability to imagine that played an important role in scientific discourses of such as geology and astronomy, but also the failure to imagine, as a constitutive part of an aesthetic of the sublime. As O'Connor points out, the new school of geology, often by drawing on astronomy - "the sublime science par excellence" - partook of "an aesthetic of wonder by which unlimited immensity (spatial or temporal) bewildered the mind into a temporary and pleasurable loss of rationality" (153). A seminal example of sublime geological time travel is John Playfair's description of an imaginative journey through time at Siccar Point, inspired by the geology of James Hutton.

In his "Biographical Account of the Late Dr James Hutton" (1805), Playfair described what has become famous in geological lore: the boat trip with Hutton and James Hall to Siccar Point, Berwickshire, which supposedly authenticated Hutton's theory "by the testimony of the senses" (72). ${ }^{11}$ The rocks at Siccar Point are an example of what Hutton called "angular junctions," or what in modern terms are known as unconformities. While, as Rudwick points out, several earlier naturalists had described such rock formations, Hutton reinterpreted them to confirm his theory of a cyclic "succession of worlds," in which successive rock masses are uplifted then worn down in a cyclical process (Bursting 168-69). Playfair records his impressions of listening to Hutton lecturing on the rocks:

[w] hat clearer evidence could we have had of the different formation of these rocks, and of the long interval which separated their formation, had we actually seen them emerging from the bosom of the deep? We felt ourselves necessarily carried back to the time when the schistus on which we stood was yet at the bottom of the sea, and when the sandstone before us was only beginning to be deposited, in the shape of sand or mud, from the waters of a superincumbent ocean. An epoch still more remote presented itself.... Revolutions still more remote appeared in the distance of this extraordinary perspective. The mind seemed to grow giddy by looking so far into the abyss of time. (72-73)

Hutton's discourse allows his audience to imagine themselves transported back through time, and to see geological changes happening in their mind's eye. Contemplating the rock strata, the imaginative journey back through "the abyss of time" takes the form of a sublime 


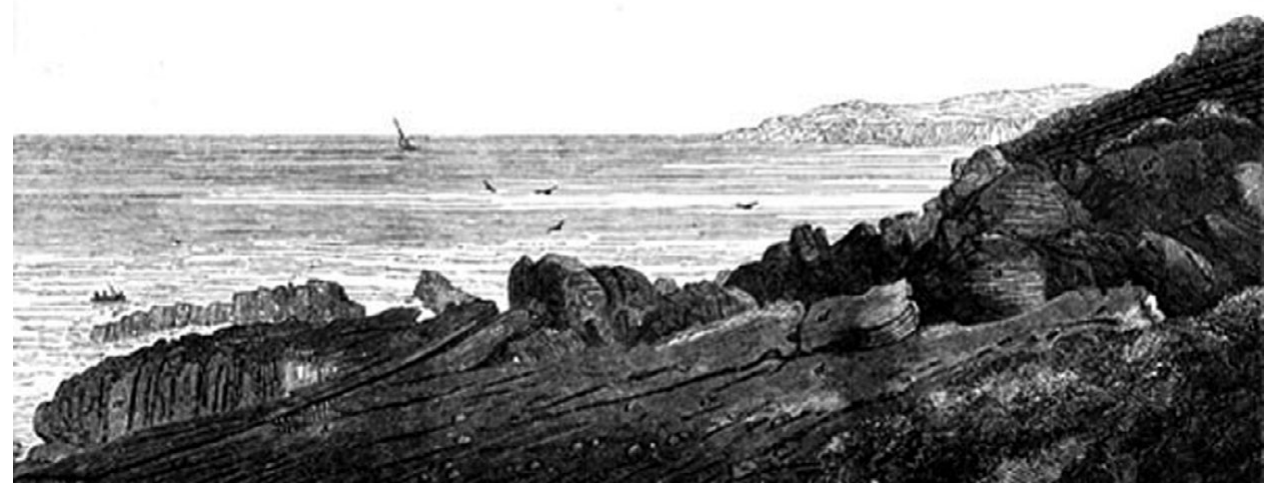

Figure 13. James Hall, "Strata of Red Sandstone, Slightly Inclined, Resting on Vertical Schist, at the Siccar Point, Berwickshire,” frontispiece to Charles Lyell's Manual of Elementary Geology (1851).

experience: "[t]he mind seemed to grow giddy," and the imagination is overwhelmed: "we became sensible how much farther reason may sometimes go than imagination can venture to follow" (73).

Playfair's description has been widely celebrated. For example, Lyell used the description of the mind growing giddy looking into "the abyss of time" as an epigram to his Manual of Elementary Geology (1851), and used an illustration of the scene at Siccar Point as a frontispiece to this work (see Figure 13). As Rudwick notes, the "idea of time as an abyss was borrowed from [Georges] Buffon, but it encapsulates what Playfair's generation (and others since) found most striking about Hutton's system" (Bursting 169).

In The Time Machine, the Traveller's journey into the distant future in many respects resembles Playfair's description of the mind's journey back through geological time. Once again, there are differences: the Traveller literally journeys into the future, whereas Playfair imagines being carried back into antiquity. Nevertheless, the Traveller's "great strides of a thousand years or more" on his machine into the deep future parallel Playfair's description of feeling "carried back to the time when the schistus on which we stood was yet at the bottom of the sea," then to "[a]n epoch still more remote," and again through "[r]evolutions still more remote," which "appeared in the distance of this extraordinary perspective." Standing on the desolate beach in the distant future, the Traveller grows "giddy." Overwhelmed, he gets off his machine to recover, and stands "sick and confused," "incapable of facing the return journey" (84-85). This giddiness is most immediately explained by the disorienting rocking of his machine, and the thinness of the air of the future. Yet it also echoes Playfair's description of the extremity of his imaginative voyage back through time: "[ $t$ ]he mind seemed to grow giddy by looking so far into the abyss of time." In the New Review version of The Time Machine, the Traveller had described his planned journey into the extreme future in terms which again echo Playfair: "I resolved to run on for one glimpse of the still remoter future - one peep into the deeper abysm of time - and then to return to you and my own epoch" (Early Writings 99). Playfair's "abyss of time" becomes Wells's "abysm of time," and his visual metaphor of "looking" becomes Wells's "glimpse" and "peep." The Time Traveller's terminus, at which he grows giddy and needs to return, is both the extreme point 
to which he can travel into a world which is increasingly unable to support life, and also parallels the limit at which the imagination becomes overwhelmed in a sublime confrontation with deep time, before needing to return to the present day.

\section{Romantic Ruins}

THE WORLD THAT THE TRAVELLER encounters in the year 802,701 AD is one of ruins. Much of the architecture of the future age is neo-Classical: there are "huge buildings with intricate parapets and tall columns," "palace-like buildings," a seat with arm rests carved as griffins' heads, and scattered cupolas and obelisks (22, 29-30). Many of the buildings are decaying or ruined, and the landscape is overgrown: it is a "tangled waste of beautiful bushes and flowers," which gives the impression of "a long-neglected" garden. There were "great palaces dotted about among the variegated greenery, some in ruins," as well as "abundant ruins," "abandoned ruins," and "splendid palaces and magnificent ruins" $(30,32,33,78)$. The Traveller pursues several of his adventures amongst ruins. Seeking shelter in a "colossal ruin," he clambers among "heaps of masonry," where he discovers a Morlock hiding "in a black shadow beneath another pile of ruined masonry"; the Traveller pursues this Morlock "into [a] second heap of ruins," unto an opening "half closed by a fallen pillar" (45-46). Later, the Traveller explores the "Palace of Green Porcelain," a deserted Victorian-style museum "falling into ruin" (64).

Patrick Parrinder has advanced an influential reading of these ruins, which he sees as a key to the time-scheme of The Time Machine. ${ }^{12}$ He points out that "the ruined buildings of the age of the Eloi and the Morlocks are, however implausibly, culturally continuous with our own civilisation" ("Rome" 116), and argues that "we can understand The Time Machine better by seeing both an '800,000-year' and an '800-year' timescale at work in it" (114): "[t]he two scales, those of historical time measured by the rise and fall of cultures and civilisations, and of biological time measured by the evolution and devolution of the species, are superimposed upon one another" (Shadows 41-42). For Parrinder, these timescales "come into conflict" when the Traveller arrives at the Palace of Green Porcelain, an episode which supposedly involves "chronological incongruities" ("Rome" 116). While the Palace would have made sense on the historical timescale, on the evolutionary timescale it is implausible: "the decay ought to have gone very much further" (Shadows 73).

However, it is not the case, as Parrinder argues, that "[w]ithout the 800-year timescale we cannot easily explain such crucial details as the survival of the unmistakably classical forms of architecture into the far future" (Shadows 42). It can be explained by reference to geological literature, and to the tropes of ruin that were widely used by geologists as a means of imagining geological time. On this reading, we need not see Wells's future landscape as an implausible conflation of two different timescales, but rather as the redeployment of tropes from geological literature in order to imagine a new form of deep time. Or, if we must follow Parrinder in holding that there are two timescales in operation in The Time Machine, these can be read not as an ungainly manipulation of the chronology of the fiction, but as an insight into geological time: that it has been conceived by geologists as an extension of historical time.

Tropes of ruin were common in geological literature, and were a nexus around which ideas of geological time clustered. In Romantic Rocks, Aesthetic Geology (2004), Noah Heringman has shown, as part of his wider argument that geology and Romantic literature 
were mutually constitutive discourses that shared a common idiom of landscape aesthetics, that Romantic poets borrowed tropes of ruin from geologists, and conversely, that geologists borrowed back from Romantic literature (180-81, 234-36). One seminal example of the use of Romantic ruins in geological literature occurs in Lyell's Principles, with his treatment of the Temple of Serapis. ${ }^{13}$

As Rudwick informs us, the so-called Temple of Serapis at Pozzuoli near Naples had been the source of a lively geological discussion since the publication of the antiquarian Andrea di Jorio's Tempio di Serapide (1820) (Adam 106-13). In his Principles, Lyell used the example of the ruined Temple - "this celebrated monument of antiquity" - to support his argument that "the relative level of land and sea has changed" (449). That is, he used "the case of Serapis, interpreted as the result of movements of the land in relation to a stationary sea level, as an epitome of his concept of a ceaselessly dynamic earth" (Rudwick, Adam 299). By drawing attention to geological change through changes wrought on the decaying columns of a classical building, and even hypothesizing that "broken fragments" of the building take part in the geological process of stratification, Lyell forged a close association between geological and architectural ruins (456). This association is reinforced by the frontispiece to the Principles (Figure 14), which depicts a man meditating on ruins of the Temple of Serapis. ${ }^{14}$ Significantly, as Rudwick remarks, this "picture symbolized Lyell's intention to use human history as the key to geohistory" (Adam 299).

Lyell's Principles made a decisive contribution to what Rudwick calls the revolutionary "historicization of the earth" (Bursting 7). His use of the Temple at Serapis is emblematic of this process of historicization. The history of the geological changes at Pozzuoli could be reconstructed in co-ordination with archaeological evidence, and with various historical accounts of the Temple. The frontispiece to the Principles thereby, as Rudwick puts it, "neatly encapsulated Lyell's ambition to integrate geohistory with human history" (Adam 299). Further, we can note that the frontispiece deploys a familiar aesthetics of the sublime. By depicting a solitary Romantic figure contemplating ruined columns, it invites the reader to consider the work's conception of geohistory, which stretches back through vast tracts of time, on the model of a sublime meditation on classical ruins.

The ruins of the future age in The Time Machine function in a similar manner to ruins in geological literature. On a hill overlooking the ruined city of the future, the Traveller contemplates the vast spans of time that he has traversed, and the changes that have happened during that period: "all the activity, all the traditions, the complex organizations, the nations, languages, literatures, aspirations, even the mere memory of Man as I knew him, had been swept out of existence" (61). The meditative Traveller here is similar to Lyell's solitary Romantic figure in the frontispiece of the Principles. ${ }^{15}$ Just as Lyell's frontispiece depicts a man contemplating the ruined columns of a classical temple, and thereby prepares his reader to join him in his meditation on the vast horizons of geological time, so too the future city with its many ruins is a suitable destination for the Time Traveller's journey through geological time, and his meditations once there on "all the years [he] had traversed" (61). Like ruins in geological literature, ruins in The Time Machine provide both the Traveller and the reader with a means of comprehending the immensity of geological time, and the course of the earth's history, which unfolds over such time.

The connection between architectural and geological ruin in Wells's romance is most closely forged through what is arguably the single most important ruin of the future age: the Palace of Green Porcelain. On his adventures, the Traveller visits the Palace, which 


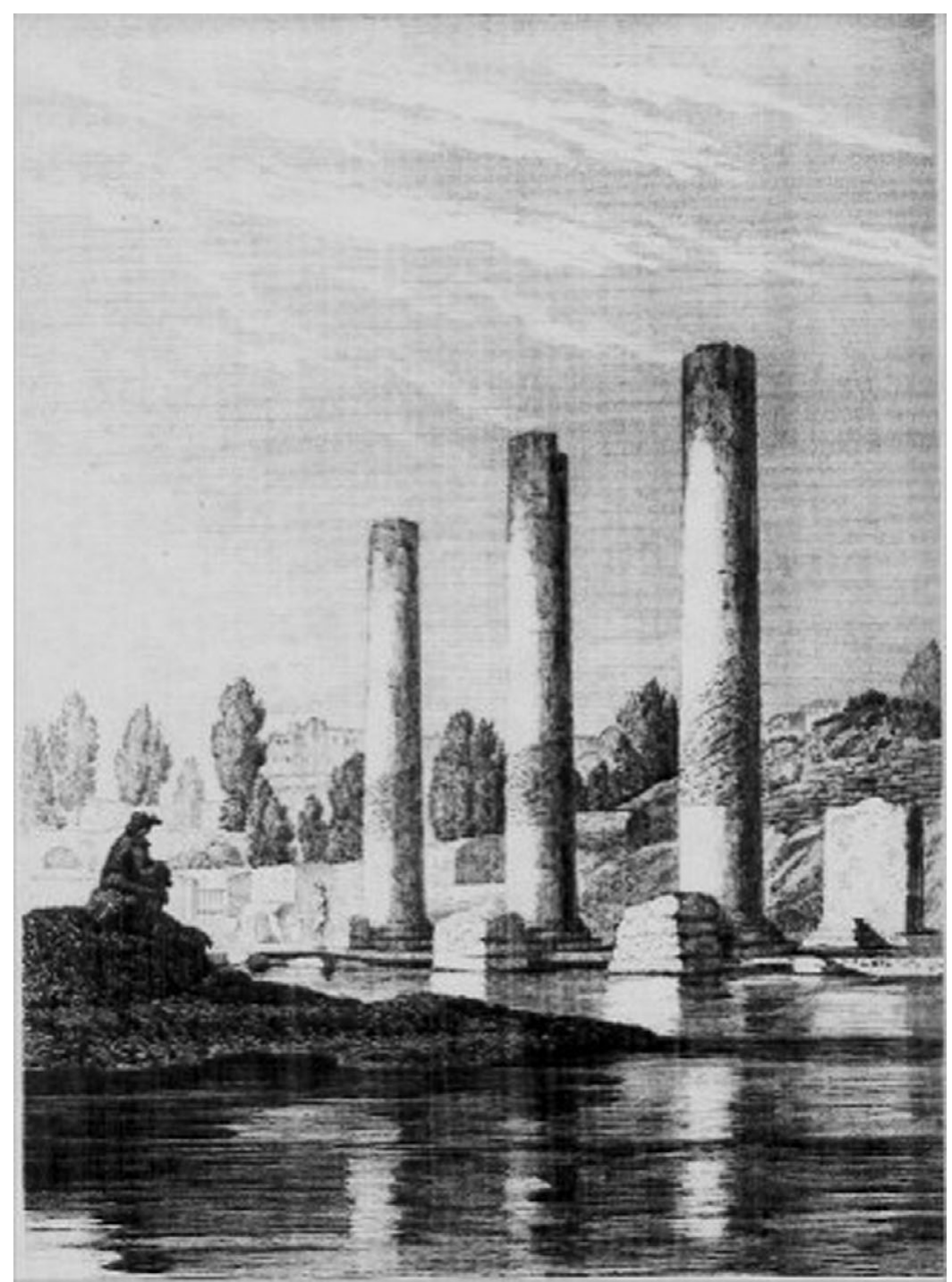

Figure 14. T. Bradley, "Present state of the Temple of Serapis at Puzzuoli," frontispiece to Charles Lyell's Principles of Geology (1830).

he describes as "the ruins of some latter-day South Kensington" (65). This Victorian-style museum, which is modelled in part on the South Kensington Museum, has decayed, and become a sublime ruin (Shadows 43-44). Inside the deserted building, the Traveller identifies "the Palaeontological Section, and a very splendid array of fossils it must have been," and recognizes "some extinct creature after the fashion of the Megatherium" and "the huge skeleton barrel of a Brontosaurus." He also discovers a gallery "devoted to minerals," and a section that "had been devoted to natural history" (64-66). 
By portraying a ruined museum with decaying exhibitions of fossils, minerals and other geological phenomena, Wells plays on the conventional figuration in geological literature of geological phenomena as ruins. The decaying geological exhibits in the museum are not figured as architectural ruins, but rather are housed in an architectural ruin. In the Origin of Species (1859), Charles Darwin drew attention to the "paltry display" that is found even in "our richest geological museums," in order to illustrate his contentions that only a small part of the geological record has survived, and that we have only fragmentary evidence of the "infinite number of generations" that "must have succeeded each other in the long roll of years" (287). Wells extended Darwin's conceit by depicting a Victorian-style museum and its already-poor paleontological collection as having undergone a further, second-order process of decay. The dinosaur skeletons and fossils - which themselves are vestiges from the distant geological past - have once again become subject to processes of decay since being exhibited. For example, the "skull and the upper bones" of the Megatherium-like creature lay "in the thick dust, and in one place, where rain-water had dropped through a leak in the roof, the thing itself had been worn away." As the Traveller comments, "the inevitable process of decay" was "with extreme sureness if with extreme slowness at work again upon all its treasures" (64-65). Wells's Palace thereby stands as a monument to a longer geological history that has been marked by loss and extinction.

Arguably, the Palace stands as an implicit critique of the spectacular culture from which The Time Machine emerged. Another model for the Palace - alongside the South Kensington Museum - was the Crystal Palace at Sydenham (Shadows 43-44). The building at this site housed the contents of the Great Exhibition of 1851, but it was also surrounded by a famous Victorian geological spectacle: the series of life-sized sculptures of extinct animals built in 1853, and displayed in the Crystal Palace Gardens. ${ }^{16}$ This display was arranged in the form of a temporal panorama, which both allowed visitors to imagine that they were travelling through time as they strolled from one geological epoch to the next, and made a long stretch of the geological past simultaneously visible as a spectacle (O'Connor 279). In the latter case, as Richard Owen's accompanying guidebook put it, the exhibition was an "attempt to reproduce and present to human gaze and contemplation the forms of animal life that have successively flourished during former geological phases of time" (7). The exhibition is thereby a central example of the phenomenon charted by O'Connor, whereby the earth's past was turned into a visual spectacle that could be consumed by an eager public. "Deep time," as he puts it, "became a consumable spectacle" (315). Wells's Palace is, like the Crystal Palace, both a site of "time travel" and a site of spectacle. However, while the Crystal Palace had been a pre-eminent Victorian spectacle, Wells's Palace of Green Porcelain has fallen into decay. It stands as a dark prophecy and warning of a spectacular society driving itself to ruin.

Ultimately, the ruins of The Time Machine are more sublime than those of Lyell's uniformitarian geology. For both Hutton and Lyell, the processes of ruin to which the earth was subject were counterbalanced by processes of renewal. For instance, Hutton's confidence in geological renovation led to the famous conclusion of his Theory of the Earth (1795), that "we find no vestige of a beginning, - no prospect of an end" (200). ${ }^{17}$ However, Wells's romance, reflecting later developments in evolutionary biology and thermodynamic physics, imagines a bleaker future. Evolutionary biology embraced the extended timescales of geologists such as Lyell, but raised the possibility that humans might suffer biological retrogression or degeneration. Physical theorists such as William Thomson argued that the 
earth was younger than geologists had claimed, and - contravening Hutton's optimistic conclusion that we find "no prospect of an end" - that it was undergoing a physical decay through the dissipation of mechanical energy. The Time Machine combines the vastly extended geological time of Hutton and Lyell, with an evolutionary scenario in which humanity has degenerated into distinct species, and a thermodynamic scenario in which the earth suffers a heat-death. ${ }^{18}$ These two forms of decay over deep time become part of the meaning of the ruins that the Traveller visits. In particular, the sublime nature of the evolutionary and thermodynamic scenario described in the terminal beach episode, feeds back into the sublimity of the ruins.

The Traveller's journey to the desolate beach is one of sublime horror. He finds no easily recognizable descendants of humans: not even the degenerate Eloi and Morlocks of the year 802,701 A.D. Instead, he encounters a "thing like a huge white butterfly," and "monstrous crab-like [creatures]"; travelling further into the future, even this "crawling multitude of crabs" has disappeared, and the beach appears "lifeless." The physical effects brought about by the dissipation of energy are similarly nightmarish, and the Traveller watches "the life of the old earth ebb away" with a "strange fascination" that turns to horror. He describes how a "horror of this great darkness came on me," and of how in the "rayless obscurity" he was struck by a "terrible dread of lying helpless in that remote and awful twilight." His experience is described in the lexicon of the sublime: "obscurity," "horror," "terrible," "dread," "awful" (82-85). It adds a sublime dimension to the deep time of The Time Machine that was absent from Hutton's and Lyell's conceptions of geological time.

In turn, the sublimity of the desolate beach feeds back into the ruins of the future age, which stand as monuments to the deep time of the romance. By foreshadowing the future destruction of the earth, Wells's ruins more closely resemble those of Andrew Ure's A New System of Geology (1829), than those of Lyell's Principles. For Ure, whose work forms part of a wider apocalyptic current in nineteenth-century geology, the "mighty ruins" of the earth "serve to rouse its living observers from their slumberous existence," leading them "to meditate seriously on the origin and end of terrestrial things" (liii). Geological ruins point forward prophetically to the eschaton: "the very stones cry out," and "we feel transported along with them to the judgment-seat of the Eternal" (505). Despite being set within a tale underpinned by a secular cosmology, the ruins of The Time Machine also function prophetically. Emblematic of the processes of biological and physical decay, they anticipate not the Day of Judgment imagined by Ure, but the frozen waste beaches of a slowly dying earth.

\section{Geological Time and Narrative}

A CENTRAL THESIS OF GILLIAN Beer's Darwin's Plots (1983) is that "evolutionary theory had particular implications for narrative and the composition of fiction" (5). She argues that: "Victorian novelists increasingly seek a role for themselves within the language of the text as observer or experimenter, rather than as designer or god. Omniscience goes, omnipotence is concealed" (40). The Time Machine can be placed within this movement: its narrative can be viewed in light of the geological and evolutionary theory that shapes so much of its content.

Rather than being a non-focalized narrative, associated with an omniscient narrator, The Time Machine is a variable internally focalized narrative, consisting of a frame-narrative 
told by a first-person narrator, and the autodiegetic narrative of the Time Traveller. ${ }^{19}$ The narratives of the various versions of The Time Machine are, in different ways, fragmentary. In the National Observer and New Review versions, the Traveller's narrative of his voyage into the future is repeatedly interrupted by objections and comments from his sceptical audience, to the extent that he at one point breaks off his story. We learn how the Traveller was eventually appeased, and "produced some few further fragments of his travel story" (Definitive 162-63). In the final version of The Time Machine, the Traveller's narrative is embedded within the frame-narrative as the incomplete fragment of a greater story, the rest of which has been lost by his failure to return from his second voyage. The frame-narrator recalls how he was left "waiting for the second, perhaps still stranger story" (90). These fragmentary narrative forms reflect Lyell and Darwin's views of the narratives that could be told about the geological and biological past.

Lyell and Darwin both stressed that our knowledge of the geological past is incomplete. In the Principles of Geology, Lyell took great pains to show that the geological record is incomplete as part of his defence of his "doctrine of absolute uniformity," against the arguments of the catastrophists (87). Such incompleteness supported his conception of a vast past across which geological processes operated slowly and uniformly, as opposed to the shorter, violent histories of the catastrophists (96-97). The Principles, as James Secord makes clear, "claimed that any kind of global narrative would prove impossible to reconstruct, as too much of the record had been lost" (xix).

Darwin, drawing on Lyell, also stressed the fragmentary nature of the geological record in the Origin of Species. He acknowledged that "the most obvious and gravest objection which can be urged against [his] theory" of evolution by natural selection is that there is no evidence of the "innumerable transitional links" between different stages of evolving species. His response to this objection was that " $[\mathrm{t}]$ he explanation lies ... in the extreme imperfection of the geological record" (279-80). For Darwin, even if our knowledge were perfect, there simply would not be sufficient evidence to create a complete record of the past. Following Lyell, he figured the incomplete geological record as a fragmentary book:

[f]or my part, following out Lyell's metaphor, I look at the natural geological record, as a history of the world imperfectly kept... [O]f this history we possess the last volume alone, relating only to two or three countries. Of this volume, only here and there a short chapter has been preserved; and of each page, only here and there a few lines. (310)

Far from resulting in a complete, universal narrative of the world's history, the metaphor of the temporal legibility of the geological landscape leads to a fragmentary, incomplete "history of the world imperfectly kept."

In The Time Machine, Wells mirrored Lyell and Darwin's idea of a fragmentary narrative history of the world. Like other Victorian writers, he employed a form of narrative breakdown to replicate what Adelene Buckland has called (following Secord) the "anti-narrative" of geologists such as Lyell $(26-27,110)$. The fragmentary form of Wells's romance mirrors both the book of the world imagined by Darwin, with its various chapters and pages missing, and the incomplete geological record for which Darwin's book is a figure. In the latter case, the gaps in Wells's narrative function like geological unconformities (albeit unconformities that point towards the geological future as well as to the past). Like the gaps in the geological record at Siccar Point, they point towards enormous lapses of time, for which no record 
has been left. Of course, these "narrative unconformities" - as they might be called - are, just like their geological counterparts, open to a variety of interpretations. The guests who remain sceptical of the Traveller's disappearance and his story, thinking it some kind of a hoax, are like the ancients whom Lyell excoriated in the Principles, for being unable to read the history of the earth, despite it being clearly written in the geological landscape that surrounded them (20). By contrast, the frame-narrator who believes the Traveller, and interprets the disappearance of the second part of his story as evidence of the truth of his tale, is like the modern geologist who appreciates the temporal significance of the landscape, and can interpret geological unconformities as revealing the great age of the earth.

Just as the geological record provides only a fragmentary record of the past, so the Traveller's narrative provides only a fragmentary account of the future. In a variation on the metaphor of legibility, the frame-narrator of The Time Machine uses a metaphor of partial illumination to describe the knowledge that the Traveller's narrative gives him of the deep future: "to me the future is still black and blank - is a vast ignorance, lit at a few casual places by the memory of his story" (91). The description of the deep future as "blank" echoes Darwin's frequent descriptions of the geological past containing blank periods, often of enormous duration. Darwin writes, for instance, that "there will be blanks in our geological history" (173), and that "between each successive formation, we have, in the opinion of most geologists, enormously long blank periods" (284). Again, the narrator's metaphor of illumination resonates with a nexus of similar Enlightenment metaphors in geological literature, in which the vast geological past is portrayed as being dark and obscure, and of geological investigation either illuminating or filling in these gaps. Roderick Murchison, for instance, to whom Wells paid tribute as one of the "great generation" of geologists alongside Lyell, used similar metaphors in his Silurian System (1839) (Autobiography 228). Murchison held that, while other geologists contend that "as yet we gaze but dimly into the obscure vista of these early periods," his work aims, by investigating the Silurian system, "to fill up an interval of geological history" $(3,12)$. Wells later used very similar metaphors of darkness and illumination to describe the discovery of the remote geological past in The Discovery of the Future (1902), an important text that marks a transition between his early scientific romances and his later "futurological" writings (41). Whereas previously the remote past had been a blank "darkness" (47), this all changed with the comparatively recent discovery of "the geological past" by "modern science" (43): rock formations "became sources of dazzling and penetrating light, - the remoter past lit up and became a picture" (49). For the frame-narrator, the Traveller's narrative fragment illuminates a few places of the deep future, just as for geologists, legible geological fragments illuminate sections of the geological past.

The Traveller's account of his adventures in the future, which constitutes the bulk of the narrative of The Time Machine, has survived only by chance. His adventures form a catalogue of near-escapes: his time machine is captured; he narrowly escapes from the Morlocks, first in their underground cavern, then in the woods and finally from their ambush; he flees from giant crabs; and he only just manages to avoid fainting and perishing in the far future. If any of these near-escapes had been fatal, the Traveller would not have returned to tell his story. This narrative logic of chance survival mirrors the chance survival by which part of the geological record remains to us. It is an analogue to the process by which a jar of camphor in the Palace of Green Porcelain had "chanced to survive" in "the universal decay," and 
the ink of the Belemnite had survived despite being fossilized "millions of years ago" (68). Moreover, the chance survival of the narrative reflects the contingency, as opposed to design, that forms part of the process of evolution by natural selection. As Beer observes, Darwin concentrated in the Origin of Species on the mechanism of "natural selection" in creating change; unlike "artificial selection," there is no guiding authority that oversees this process (8). The Time Machine supposedly came into existence in a similarly undesigned manner, and thus formally embodies a logic analogous to that which has led to the nightmarish consequences of degeneration in the far future. Conversely, the loss of the Traveller's second story reflects the themes of loss and extinction that play such major roles in the romance. It reflects the loss that characterizes both geology, with the disappearance of the greater part of the fossil record over time, and evolutionary biology, with the extinction of species over what Darwin called "the long roll of years."

The fragmentary narrative form of The Time Machine contributes to the sublimity of the deep time depicted therein. "Obscurity" has long played an important role in conceptualizations of the sublime. For example, in his Philosophical Enquiry in the Origin of our Ideas of the Sublime and Beautiful (1756/9), Edmund Burke held that "terror is in all cases whatsoever, either more openly or latently the ruling principle of the sublime" (97), and that " $[\mathrm{t}] \mathrm{o}$ make any thing very terrible, obscurity seems in general to be necessary" (99). While the frame-narrator's depiction of the deep future as "black and blank" echoes similar metaphors in geological discourse about the geological past, it is also one of obscurity; the deep future that the Traveller visits thereby becomes, in Burke's terms, "very terrible."

More importantly, the fragmentary form of the romance contributes to its articulation of an inhuman geological time. According to the narrative theories of Frank Kermode and Paul Ricoeur, narrative humanizes time. Kermode characterizes plot as "an organization that humanizes time by giving it form" (45), and Ricoeur argues that "time becomes human time to the extent that it is organized after the manner of a narrative" (3). Conversely, through its resistance to narrative organization, the geological time of The Time Machine remains inhuman; it forms part of a universe that is eminently inhospitable to humanity. Wells's romance does not allow a poetic resolution for humanity, dwarfed by the abyssal geological time of Hutton and Lyell. Rather, it emphasizes humanity's insignificant and precarious position within a hostile universe, encapsulated by its closing image of the Traveller lost somewhere in the vast expanses of time.

St Catherine's College, Oxford.

\section{NOTES}

1. There are five extant versions of The Time Machine. An early version of the romance, "The Chronic Argonauts," appeared in the Science School Journal in 1888. The Time Machine was published in serialised form in the National Observer in 1894, and in the New Review in 1894-95; it was published in book form by Henry Holt and Co. in America, and by William Heinemann in Britain, both in 1895 . For an account of the publication history of The Time Machine, see Geduld 5-10.

2. The "Normal School of Science" changed its name to the "Royal College of Science" in 1890, before eventually becoming absorbed into Imperial College London. 
3. Unless otherwise specified, all references are to Parrinder's edition of The Time Machine.

4. Although he does not explicitly mention The Time Machine, O'Connor intriguingly suggests that from geological time travel it "was only a short step to the scientific romances of ... H. G. Wells" (374).

5. In his Autobiography, Wells recorded his interest in the geology "of that great generation which included Lyell" (228).

6. On the influence of Lyell's geology on Tennyson, see Dean's Tennyson and Geology, and Zimmerman's Excavating Victorians 65-96.

7. Wells recalls having read Tennyson as a student (Autobiography 240).

8. Hovanec has compared the Traveller's voyages to those afforded by the pre-cinematic visual technologies of the Victorian era, and has contended that his time machine is itself such a technology (473-74). Here, I suggest that the closest parallel is to those technologies that portrayed geological time travel.

9. In his Autobiography, Wells recalls his "excitement" at realizing, while standing on the brow of Telegraph Hill, and looking across the weald to the North Downs, that "I was standing on the escarpment of a denuded anticlinal, and that this stuff of the pale hills under my feet had once been slime at the bottom of a vanished Cretaceous sea" (144).

10. This chapter is reproduced in Definitive Time Machine 184-88.

11. Wells would have known of Hutton. Hutton's work, and its "influence on the growth of the Science of Geology," is the subject of the first chapter of R. D. Roberts's The Earth's History (1893) (4-13), a work to which Wells and Gregory refer their readers in Honours Physiography (118).

12. Parrinder first advanced this argument in Shadows (1995), and then later in "Rome" (2001). As McLean notes, "Parrinder's idea that there are two timescales at work in The Time Machine [has been] generally accepted" (12).

13. See also the extended conceit in which Lyell compares geological history to the architectural history of Egypt, with its "pyramids, obelisks, colossal statues, and ruined temples" (Principles 26-28).

14. This frontispiece is a copy of a very similar illustration from Jorio's Tempio di Serapide: see Lyell, Principles xiv; and Rudwick, Adam 108, 299.

15. Wells undoubtedly knew about the Temple of Serapis: he and Gregory referred to it in their Honours Physiography (122). Bonney also discussed this "often quoted" example in his Story of Our Planet, and provided an alternative illustration of the ruined columns (222-26).

16. Wells recalls first becoming aware of the earth's expansive past when being taken to see the Crystal Palace monsters as a child (Autobiography 97-98); his hero revisits the monsters in Kipps (1905).

17. See also his Theory of the Earth (1795), 200.

18. More specifically, the heat-death scenario envisaged in The Time Machine is - as the Traveller remarks inflected by G. H. Darwin's theory of "tidal drag" $(45,82)$.

19. Geduld suggests that this narrator is Hillyer, whom the Traveller "seemed to see... but he passed like a flash" (118).

\section{WORKS CITED}

Beer, Gillian. Darwin's Plots: Evolutionary Narrative in Darwin, George Eliot, and Nineteenth-Century Fiction. 3rd ed. Cambridge: Cambridge UP, 2009.

Bonney, T. G. The Story of our Planet. London: Cassell, 1893.

Buckland, Adelene. Novel Science: Fiction and the Invention of Nineteenth-Century Geology. Chicago: U of Chicago P, 2013.

Burke, Edmund. A Philosophical Enquiry into the Origin of our Ideas of the Sublime and Beautiful. 2nd ed. London: R. and J. Dodsley, 1759.

Clarke, Bruce. Energy Forms: Allegory and Science in the Era of Classical Thermodynamics. Ann Arbor: U of Michigan P, 2001. 
Darwin, Charles. On the Origin of Species by Means of Natural Selection, Or the Preservation of Favoured Races in the Struggle for Life. London: John Murray, 1859.

Dean, Dennis. Tennyson and Geology. Lincoln: Tennyson Society, 1985.

Geduld, Harry M. "Introduction." The Definitive Time Machine: A Critical Edition of H. G. Wells's Scientific Romance. Bloomington: Indiana UP, 1987. 1-27.

Greenslade, William. Degeneration, Culture and the Novel, 1880-1940. Cambridge: Cambridge UP, 1994. Gregory, R. A. and H. G. Wells. Honours Physiography. London: Joseph Hughes, 1893.

Heringman, Noah. Romantic Rocks, Aesthetic Geology. Ithaca: Cornell UP, 2004.

Hovanec, Caroline. "Rereading H. G. Wells's The Time Machine: Empiricism, Aestheticism, Modernism." ELT 58.44 (2015): 459-85.

Hutton, James. Theory of the Earth, with Proofs and Illustrations. Vol. 1. Edinburgh: William Creech, 1795.

James, Simon J. Maps of Utopia: H. G. Wells, Modernity, and the End of Culture. Oxford: Oxford UP, 2012.

Kermode, Frank. The Sense of an Ending: Studies in the Theory of Fiction. New ed. Oxford: Oxford UP, 2000.

Lyell, Charles. A Manual of Elementary Geology: Or, the Ancient Changes of the Earth and its Inhabitants as Illustrated by Geological Monuments. 3rd ed. London: John Murray, 1851.

Lyell, Charles. Principles of Geology: Being an Attempt to Explain the Former Changes of the Earth's Surface, by Reference to Causes Now in Operation. Vol. 1. London: John Murray, 1830.

McConnell, Frank. The Science Fiction of H. G. Wells. Oxford: Oxford UP, 1981.

McLean, Steven. The Early Fiction of H. G. Wells: Fantasies of Science. London: Palgrave Macmillan, 2009.

Murchison, Roderick. The Silurian System. Vol. 1. London: John Murray, 1839.

O'Connor, Ralph. The Earth on Show: Fossils and the Poetics of Popular Science, 1802-1856. Chicago: U of Chicago P, 2007.

Owen, Richard. Geology and Inhabitants of the Ancient World. London: Crystal Palace Library, 1854.

Parrinder, Patrick. "From Rome to Richmond: Wells, Universal History, and Prophetic Time." H. G. Wells's Perennial Time Machine. Ed. George Slusser et al. Athens: U of Georgia P, 2001. 110-21.

Parrinder, Patrick. Shadows of the Future: H. G. Wells, Science Fiction and Prophecy. Liverpool: Liverpool UP, 1995.

Playfair, John. "Biographical Account of the Late Dr James Hutton, F. R. S. Edin." Transactions of the Royal Society of Edinburgh 5.3 (1805): 39-99.

Ricoeur, Paul. Time and Narrative. Trans. Kathleen McLaughlin and David Pellauer. Vol. 1. Chicago: U of Chicago P, 1984.

Roberts, R. D. The Earth's History: An Introduction to Modern Geology. London: John Murray, 1893.

Rudwick, Martin J. S. Bursting the Limits of Time: The Reconstruction of Geohistory in the Age of Revolution. Chicago: U of Chicago P, 2005.

Rudwick, Martin J. S. "The Strategy of Lyell's Principles of Geology.” Isis 61.1 (Spring 1970): 5-33.

Rudwick, Martin J. S. Worlds Before Adam: The Reconstruction of Geohistory in the Age of Reform. Chicago: U of Chicago P, 2008.

Sayeau, Michael. Against the Event: The Everyday and the Evolution of Modernist Narrative. Oxford: Oxford UP, 2013.

Secord, James A. "Introduction.” Principles of Geology by Charles Lyell. London: Penguin, 1997. ix-xliii. Tennyson, Alfred. In Memoriam. Ed. Susan Shatto and Marion Shaw. Oxford: Clarendon P, 1982.

Thomson, William. "On a Universal Tendency in Nature to the Dissipation of Mechanical Energy." Mathematical and Physical Papers. Vol. 1. Cambridge: Cambridge UP, 1882. 511-14.

Ure, Andrew. A New System of Geology. London: Longman et al., 1829.

Wells, H. G. The Definitive Time Machine: A Critical Edition of H. G. Wells's Scientific Romance. Ed. Harry M. Geduld. Bloomington: Indiana UP, 1987.

Wells, H. G. The Discovery of the Future. London: T. Fischer Unwin, 1902. 
Wells, H. G. Early Writings in Science and Science Fiction. Ed. Robert M. Philmus and David Y. Hughes.

Berkeley: U of California P, 1975.

Wells, H. G. Experiment in Autobiography: Discoveries and Conclusions of a Very Ordinary Brain (Since 1866). Vol. 1. Victor Gollancz and The Cresset Press, 1934.

Wells, H. G. "Reminiscences of a Planet." Pall Mall Gazette 58.8990 (1894): 4.

Wells, H. G. The Time Machine. Ed. Patrick Parrinder. London: Penguin, 2005.

Willis, Martin. Vision, Science and Literature, 1870-1920: Ocular Horizons. London: Pickering \& Chatto, 2011.

Zimmerman, Virginia. Excavating Victorians. Albany: State U of New York P, 2008. 